\title{
CT differential diagnosis of COVID-19 and non-COVID-19 in symptomatic suspects: a practical scoring method
}

\author{
Lin Luo ${ }^{1 \dagger}$, Zhendong Luo ${ }^{1 \dagger}$, Yizhen $\mathrm{Jia}^{2}$, Cuiping Zhou', Jianlong He${ }^{1}$, Jianxun Lyu ${ }^{1}$ and Xinping Shen ${ }^{1 *}$
}

\begin{abstract}
Background: Although typical and atypical CT image findings of COVID-19 are reported in current studies, the CT image features of COVID-19 overlap with those of viral pneumonia and other respiratory diseases. Hence, it is difficult to make an exclusive diagnosis.

Methods: Thirty confirmed cases of COVID-19 and forty-three cases of other aetiology or clinically confirmed nonCOVID-19 in a general hospital were included. The clinical data including age, sex, exposure history, laboratory parameters and aetiological diagnosis of all patients were collected. Seven positive signs (posterior part/lower lobe predilection, bilateral involvement, rounded GGO, subpleural bandlike GGO, crazy-paving pattern, peripheral distribution, and GGO +/- consolidation) from significant COVID-19 CT image features and four negative signs (only one lobe involvement, only central distribution, tree-in-bud sign, and bronchial wall thickening) from other nonCOVID-19 pneumonia were used. The scoring analysis of $\mathrm{CT}$ features was compared between the two groups (COVID-19 and non-COVID-19).
\end{abstract}

Results: Older age, symptoms of diarrhoea, exposure history related to Wuhan, and a lower white blood cell and lymphocyte count were significantly suggestive of COVID-19 rather than non-COVID-19 $(p<0.05)$. The receiver operating characteristic (ROC) curve of the combined $C T$ image features analysis revealed that the area under the curve (AUC) of the scoring system was 0.854 . These cut-off values yielded a sensitivity of $56.67 \%$ and a specificity of $95.35 \%$ for a score $>4$, a sensitivity of $100 \%$ and a specificity of $23.26 \%$ for a score $>0$, and a sensitivity of $86.67 \%$ and a specificity of $67.44 \%$ for a score $>2$.

Conclusions: With a simple and practical scoring system based on CT imaging features, we can make a hierarchical diagnosis of COVID-19 and non-COVID-19 with different management suggestions.

Keywords: Coronavirus infections, Pneumonia, Tomography, x-ray computed, Lung diseases

\footnotetext{
* Correspondence: szshenxinping@163.com

${ }^{\dagger}$ Lin Luo and Zhendong Luo contributed equally to this work.

'Department of Radiology, The University of Hong Kong - Shenzhen Hospital, No.1, Haiyuan road Futian District, Shenzhen 518000, China

Full list of author information is available at the end of the article
}

(c) The Author(s). 2020 Open Access This article is licensed under a Creative Commons Attribution 4.0 International License, which permits use, sharing, adaptation, distribution and reproduction in any medium or format, as long as you give appropriate credit to the original author(s) and the source, provide a link to the Creative Commons licence, and indicate if changes were made. The images or other third party material in this article are included in the article's Creative Commons licence, unless indicated otherwise in a credit line to the material. If material is not included in the article's Creative Commons licence and your intended use is not permitted by statutory regulation or exceeds the permitted use, you will need to obtain permission directly from the copyright holder. To view a copy of this licence, visit http://creativecommons.org/licenses/by/4.0/ The Creative Commons Public Domain Dedication waiver (http://creativecommons.org/publicdomain/zero/1.0/) applies to the data made available in this article, unless otherwise stated in a credit line to the data. 


\section{Background}

The 2019 novel coronavirus disease (COVID-19) has become a global viral pandemic and a public health problem of international concern. According to the guidelines for COVID-19 (Trial Version 7th) China [1], confirmed COVID-19 cases need to be referred to a designated hospital while suspected cases need to be quarantined under medical surveillance. The medical care for quarantined patients and isolation for people with whom they have had close contact requires larger public health surveillance and response systems with an enormous medical burden. Chest CT can yield a quick positive result prior to positive real-time fluorescence polymerase chain reaction (RT-PCR), which is the gold standard for confirming COVID-19 at present [2] but with a notable false negative rate [3-5]. Although typical and atypical CT image findings are reported in several papers [2, 6-15], overlapping CT image features with viral pneumonia and other respiratory diseases also make an exclusion diagnosis difficult. We attempted to develop a simple and practical method to stratify cases requiring different repetition times of RT-PCR to identify highly suspicious cases and highly excluded cases.

\section{Methods}

\section{Patients}

We retrospectively enrolled 91 patients fulfilling the inclusion criteria: patients who underwent high-resolution CT within 7 days after the onset of symptoms and had the first consultation at the general hospital from Jan 10 to Feb 28, 2020. Of those 91 patients, 30 cases of COVID-19 were confirmed with WHO interim guidance, and 43 cases of other aetiology or clinically confirmed non-COVID-19 were finally included in our cohort. Suspected COVID-19 cases with abnormal chest CT findings (one COVID-19 and 1 non-COVID-19 with normal chest CT were excluded) were included with the following inclusion criteria [1]: (1) epidemiological exposure history within 14 days before the onset of symptoms - i) travel/residence history in Wuhan; ii) travel/ residence history in Hubei but not Wuhan; iii) exposure history to confirmed cases or community, respiratory symptoms related patient; iv) cluster onset; (2) presented with fever and/or respiratory symptoms within 7 days of CT examination; and (3) normal or low white blood cell count and lymphocyte count at early onset. The exclusion criteria were as follows: (1) images with excessive motion artefact (one non-COVID-19 was excluded); (2) children and pregnant women (three COVID-19 and 9 non-COVID-19 were excluded); (3) lost to follow-up (three non-COVID-19).

The clinical data including age, sex, exposure history and laboratory parameters of all patients are summarized in Table 1
Pathogenic evidence: a nucleic acid test by RT-PCR was used to detect the new coronavirus in respiratory samples. All enrolled patients had final diagnoses of twice-positive RT-PCR to confirm COVID-19, more than or equal to twice-negative RT-PCR (range 2-5 times) or at least one negative RT-PCR with other pathogens (mycoplasma pneumonia, human immunodeficiency virus and influenza) confirmed, or community-acquired pneumonia of unknown cause with resolved follow-up chest CT findings after treatment.

\section{CT image data acquisition}

CT images of the thorax were acquired using the automatic exposure control setting and scan range, and the noise index of was 12.3 . CT scans were performed $\leq 7$ days after symptom onset on a helical 64-slice CT GE (Lightspeed Ultra 16, USA; $1.25 \mathrm{~mm}$ slice thickness; 1.5 pitch; 120 kVP tube voltage; 100-200 mAs tube current; sagittal and coronal reconstruction thickness, $3 \mathrm{~mm}$ with 3-mm intervals) or Siemens (Somatom Definition AS, Germany; $1 \mathrm{~mm}$ slice thickness; 1.2 pitch; $120 \mathrm{kVP}$ tube voltage; 100-200 mAs tube current; sagittal and coronal reconstruction thickness, $3 \mathrm{~mm}$ with 3 -mm intervals; and a sharp reconstruction kernel).

\section{CT image analysis}

We summarized several significant COVID-19 CT image features by reviewing recently reported papers published or e-published on chest CT findings from the COVID19 outbreak in China in Table 2. Referring to other CT image signs in viral pneumonia $[16,17]$ or communityacquired pneumonia $[16,18]$, we set seven positive signs from significant COVID-19 image features and four negative signs from significant image features of other non-COVID-19 pneumonia as in Table 3 and Fig. 1. In brief, visual scores were defined as follows: score 1, positive significant COVID-19 image features; score-1, non-COVID-19 with viral pneumonia or communityacquired pneumonia of unknown cause image features. An overall score was reached by summing the scores of the eleven features in Table 4.

The image analysis focused on the features of each patient, including (a) number of lobes involved, (b) lesions and distribution characteristics (e.g., peripheral distribution, central distribution, subpleural distribution, and posterior distribution), (c) lesion patterns (e.g., ground glass opacification (GGO) with or without consolidation, crazy-paving pattern, and the shape of the GGO), (d) other signs in the lesion (e.g., bronchial and/or bronchiolar wall thickening), and (e) other findings (e.g., tree-inbud sign). All CT findings were described according to the Fleischner Society recommendations and similar studies [19-21]. Peripheral distribution was defined as any lesion affecting a peripheral area $(3-4 \mathrm{~cm}$ in 
Table 1 The clinical data including age, sex, exposure history and laboratory parameters of all the collected patients

\begin{tabular}{|c|c|c|c|c|c|}
\hline Parameter & $\begin{array}{l}\text { All patients } \\
\boldsymbol{N}=73\end{array}$ & $\begin{array}{l}\text { RT-PCR confirmed } \\
\text { COVID-19 } \\
\mathbf{N}=30\end{array}$ & $\begin{array}{l}\text { Laboratory or clinical confirmed not } \\
\text { COVID-19 } \\
\mathbf{N}=43\end{array}$ & $\begin{array}{l}\text { Test } \\
\text { statistic }\end{array}$ & $\begin{array}{l}P \\
\text { value }\end{array}$ \\
\hline Gender & & & & 0.329 & 0.566 \\
\hline Male & $37(50.7)$ & $14(46.7)$ & $23(53.5)$ & & \\
\hline Female & $36(49.3)$ & $16(53.3)$ & $20(46.5)$ & & \\
\hline Age(y) & $41(33-55.5)$ & $54(36-64)$ & $37(32-47)$ & 3.091 & $0.002^{*}$ \\
\hline Exposure History & & & & 34.717 & $\begin{array}{l}< \\
0.001^{*}\end{array}$ \\
\hline Wuhan contact & $29(39.7)$ & $24(80.0)$ & $5(11.6)$ & & \\
\hline Hubei (not Wuhan) contact & $10(13.7)$ & $2(6.7)$ & $8(18.6)$ & & \\
\hline Not Hubei contact or Cluster onset & $34(46.6)$ & $4(13.3)$ & $30(69.8)$ & & \\
\hline $\begin{array}{l}\text { Duration between } \mathrm{CT} \text { and symptom onset } \\
\text { (day) }\end{array}$ & $3(1-6)$ & $3(1-5.25)$ & $3(1-7)$ & -0.074 & 0.941 \\
\hline \multicolumn{6}{|l|}{ Symtoms } \\
\hline Fever & $45(61.6)$ & $22(73.3)$ & $23(53.5)$ & 2.943 & 0.086 \\
\hline Cough & $49(67.1)$ & $17(56.7)$ & $32(74.4)$ & 2.523 & 0.112 \\
\hline Sputum production & $19(26.0)$ & $5(16.7)$ & $14(32.6)$ & 2.318 & 0.128 \\
\hline Running/stuffy nose & $3(4.1)$ & $0(0.0)$ & $3(7.0)$ & 2.183 & 0.264 \\
\hline Fatigue & $8(11.0)$ & $2(6.7)$ & $6(14.0)$ & 1.016 & 0.314 \\
\hline Muscle ache/myalgia & $15(20.5)$ & $7(23.3)$ & $8(18.6)$ & 0.242 & 0.623 \\
\hline Diarrhea & $4(5.5)$ & $4(13.3)$ & $0(0.0)$ & 7.450 & $0.006^{*}$ \\
\hline Chest pain & $1(1.4)$ & $0(0.0)$ & $1(2.3)$ & 1.068 & 0.301 \\
\hline Sore throat & $10(13.7)$ & $2(6.7)$ & $8(18.6)$ & 2.307 & 0.129 \\
\hline Headache & $8(11.0)$ & $3(10.0)$ & $5(11.6)$ & 0.048 & 0.826 \\
\hline \multicolumn{6}{|l|}{ Laboratory Investigation } \\
\hline $\begin{array}{l}\text { White-cell count }\left(10^{-9} \mathrm{~g} / \mathrm{L} \text { ) }\right. \\
\text { (normal range } 3.89-9.93)\end{array}$ & $6.81(5.40-8.37)$ & $5.43(4.25-6.12)$ & $7.67(6.73-9.06)$ & -4.547 & $\begin{array}{l}< \\
0.001^{*}\end{array}$ \\
\hline $\begin{array}{l}\text { Neutrophil percentage(\%) } \\
\text { (normal range } 44.0-72.0 \text { ) }\end{array}$ & $\begin{array}{l}64.45(57.70- \\
73.45)\end{array}$ & $64.80(61.35-73.38)$ & $64.45(55.38-73.70)$ & 0.908 & 0.364 \\
\hline $\begin{array}{l}\text { Neutrophil count }\left(10^{-9} \mathrm{~g} / \mathrm{L} \text { ) }\right. \\
\text { (normal range } 2.01-7.42)\end{array}$ & $4.21(3.30-5.96)$ & $3.46(3.00-4.32)$ & $4.92(3.75-7.09)$ & -3.295 & $0.001^{*}$ \\
\hline $\begin{array}{l}\text { Lymphocyte percentage(\%) } \\
\text { (normal range } 20.0-45.0 \text { ) }\end{array}$ & $\begin{array}{l}26.15(18.05- \\
31.08)\end{array}$ & $25.25(17.58-31.03)$ & $26.75(18.55-32.55)$ & -0.423 & 0.673 \\
\hline $\begin{array}{l}\text { Lymphocyte count }\left(10^{-9} \mathrm{~g} / \mathrm{L} \text { ) }\right. \\
\text { (normal range } 1.06-3.61)\end{array}$ & $1.70(1.28-2.36)$ & $1.32(1.08-1.69)$ & $1.93(1.54-2.64)$ & -3.667 & $\begin{array}{l}< \\
0.001^{*}\end{array}$ \\
\hline \multicolumn{6}{|l|}{ Final diagnosis of non-COVID-19 } \\
\hline Influenza & 2 & - & 2 & & \\
\hline Mycoplasma pneumonia & 7 & - & 7 & & \\
\hline Pneumocystis carinii pneumonia & 1 & - & 1 & & \\
\hline $\begin{array}{l}\text { Community-acquired pneumonia of } \\
\text { unknown cause }\end{array}$ & 33 & - & 33 & & \\
\hline
\end{tabular}

* $P<0.05$ was considered as statistical significant

thickness at the lung periphery) with or without central distribution. Central distribution was defined as ONLY central distribution (the central tubular structures in a secondary pulmonary lobule), and any lesion with a peripheral area affected was excluded. Ground glass opacification was defined as hazy opacity that did not obscure the underlying bronchial and vascular margins; consolidation was defined as opacification with obscuration of bronchial structures and pulmonary vessels [19](Fig. 1a, b). A crazy-paving pattern is ground-glass opacity superimposed with lines of reticular patterns [22](Fig. 1c). Rounded GGO is a round-shaped GGO in 
Table 2 significant COVID-19 CT image features by reviewing reported papers published or e-published of chest CT findings from COVID-19 outbreak in China recently

\begin{tabular}{|c|c|c|c|c|c|c|c|c|}
\hline & $\begin{array}{l}\text { GGO } \\
+/- \text { consolidation }\end{array}$ & $\begin{array}{l}\text { Peripheral/ } \\
\text { subpleural } \\
\text { distribution }\end{array}$ & $\begin{array}{l}\text { Posterior part/ lower } \\
\text { lobe predilection }\end{array}$ & $\begin{array}{l}\text { Bilateral } \\
\text { involvement }\end{array}$ & $\begin{array}{l}\text { Crazy-paving } \\
\text { pattern }\end{array}$ & $\begin{array}{l}\text { Rounded } \\
\text { GGO }\end{array}$ & $\begin{array}{l}>2 \text { lobes } \\
\text { affected }\end{array}$ & $\begin{array}{l}\text { Central } \\
\text { distribution }\end{array}$ \\
\hline $\begin{array}{l}\text { Kann et al } \\
\text { [6] }\end{array}$ & $86 \%$ & $33 \%$ & - & $76 \%$ & $19 \%$ & - & - & - \\
\hline $\begin{array}{l}\text { Bernheim } \\
\text { et al [7] }\end{array}$ & $91 \%$ & $63 \%$ & - & $73 \%$ & $6 \%$ & $65 \%$ & $62 \%$ & - \\
\hline $\begin{array}{l}\text { Chung } \\
\text { et al [8] }\end{array}$ & $86 \%$ & $33 \%$ & - & $76 \%$ & $19 \%$ & $33 \%$ & $71 \%$ & - \\
\hline $\begin{array}{l}\text { Song et al } \\
\text { [9] }\end{array}$ & $<59 \%$ & $86 \%$ & $80 \%$ & $86 \%$ & $75 \%$ & - & $91 \%$ & $10 \%$ \\
\hline $\begin{array}{l}\text { Pan F et al } \\
{[10]}\end{array}$ & $75 \%$ & $54 \%$ & - & $42 \%$ & $25 \%$ & - & $58 \%$ & - \\
\hline $\begin{array}{l}\text { Zu et al } \\
{[11]}\end{array}$ & $(+++)$ & $(+++)$ & $(+++)$ & $(+++)$ & $(++)$ & - & - & - \\
\hline $\begin{array}{l}\text { Pan YY } \\
\text { et al [12] }\end{array}$ & $85.70 \%$ & - & - & - & - & - & $69.7 \%$ & - \\
\hline $\begin{array}{l}\text { Shi et al } \\
\text { [13] }\end{array}$ & $65 \%$ & $54 \%$ & - & $79 \%$ & - & - & - & - \\
\hline $\begin{array}{l}\text { Xu X et al } \\
{[14]}\end{array}$ & $72 \%$ & $51 \%$ & - & $59 \%$ & $12 \%$ & - & $73 \%$ & - \\
\hline $\begin{array}{l}\text { Xu YH et al } \\
{[15]}\end{array}$ & $75 \%$ & $<96.4 \%$ & - & $>53.6 \%$ & $75 \%$ & - & - & - \\
\hline $\begin{array}{l}\text { Guan et al } \\
{[2]}\end{array}$ & $56.40 \%$ & - & - & $51.80 \%$ & - & - & - & - \\
\hline
\end{tabular}

GGO Ground glass opacification

Table 3 Selected chest CT image features and Scores analysis

\begin{tabular}{|c|c|c|c|c|c|c|}
\hline & CT parameter & $\begin{array}{l}\text { All } \\
\text { patients } \\
\mathrm{N}=73\end{array}$ & $\begin{array}{l}\text { RT-PCR confirmed } \\
\text { COVID-19 } \\
N=30\end{array}$ & $\begin{array}{l}\text { Laboratory or clinical confirmed non- } \\
\text { COVID-19 } \\
N=43\end{array}$ & $\begin{array}{l}x^{2} \\
\text { statistic }\end{array}$ & $\begin{array}{l}\boldsymbol{P} \text { - } \\
\text { value }\end{array}$ \\
\hline \multirow{7}{*}{$\begin{array}{l}\text { Positive + } \\
1\end{array}$} & Posterior part/lower lobe predilection & $66(90.4)$ & $30(100.0)$ & $36(83.7)$ & 7.923 & $0.005^{*}$ \\
\hline & Bilateral involvement & $33(45.2)$ & $18(60.0)$ & $15(34.9)$ & 4.500 & $0.034^{*}$ \\
\hline & Rounded GGO & $9(12.3)$ & $8(26.7)$ & $1(2.3)$ & 10.226 & $0.001^{*}$ \\
\hline & Subpleural bandlike GGO & $16(21.9)$ & $14(46.7)$ & $2(4.7)$ & 18.228 & $\begin{array}{l}< \\
0.001^{*}\end{array}$ \\
\hline & Crazy-paving pattern & $37(50.7)$ & $23(76.7)$ & $14(32.6)$ & 13.755 & $\begin{array}{l}< \\
0.001^{*}\end{array}$ \\
\hline & Peripheral distribution & $58(79.5)$ & $29(96.7)$ & $29(67.4)$ & 9.245 & $0.002^{*}$ \\
\hline & GGO +/- consolidation & $66(90.4)$ & $27(90.0)$ & $39(90.7)$ & 0.010 & 0.921 \\
\hline \multirow{4}{*}{$\begin{array}{l}\text { Negative } \\
-1\end{array}$} & Only one lobe involvement & $34(46.6)$ & $9(30.0)$ & $25(58.1)$ & 5.623 & $0.018^{*}$ \\
\hline & $\begin{array}{l}\text { Only Central distribution } \\
\text { (peribronchovascular) }\end{array}$ & $15(20.5)$ & $1(3.3)$ & $14(32.6)$ & 9.245 & $0.002^{*}$ \\
\hline & $\begin{array}{l}\text { Tree-in-Bud sign (centrilobular } \\
\text { nodules) }\end{array}$ & $6(8.2)$ & $0(0.0)$ & $6(14.0)$ & 6.723 & $0.010^{*}$ \\
\hline & Bronchial wall thickening & $12(16.4)$ & $1(3.3)$ & $11(25.6)$ & 7.572 & $0.006^{*}$ \\
\hline \multicolumn{2}{|c|}{ Total Score median (IQR) } & $2(1-4)$ & $4(2-5)$ & $2(0-2)$ & 4.637 & $\begin{array}{l}< \\
0.001\end{array}$ \\
\hline
\end{tabular}



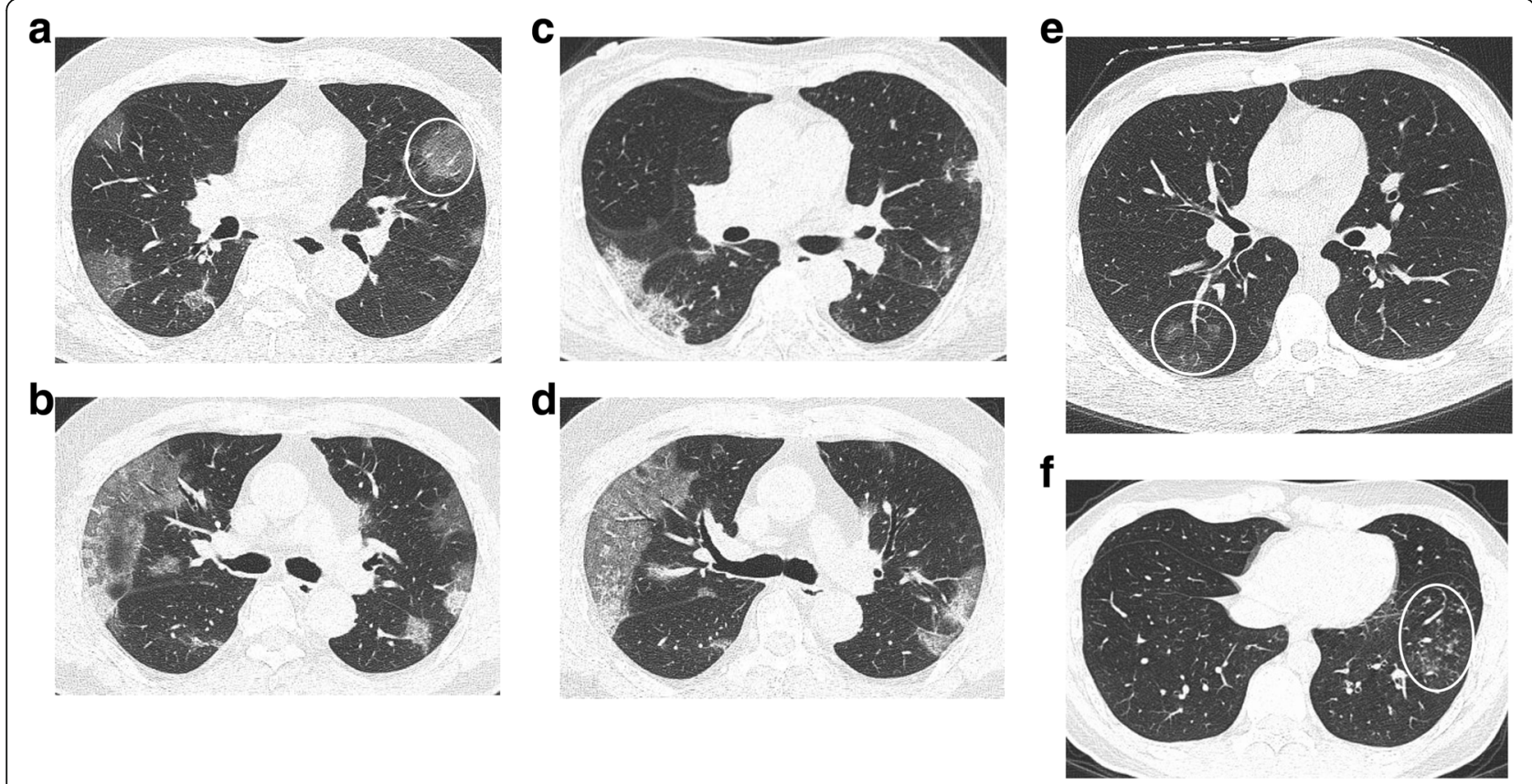

Fig. 1 a-d are the images of COVID-19. a Pure GGO and Rounded GGO (circle). b Mix GGO and consolidation. c Crazy-paving pattern. d Subpleural bandlike areas of GGO. e-f are the images of non-COVID-19. e Central (peribronchovascular) distribution (circle). f Tree-in-bud sign (circle)

any plane (Fig. 1a). The subpleural bandlike GGO is a pronounced peripheral, subpleural distribution along with axial pleura (Fig. 1d). Central (peribronchovascular) distribution was defined as typically around the bronchiolar vascular bundle and sparing the subpleural surfaces. They are typically at least $5-10 \mathrm{~mm}$ away from the pleural surfaces [23] (Fig. 1e). The tree-in-bud sign was defined as peripheral, small, centrilobular, and welldefined nodules of soft-tissue attenuation connecting to linear, branching opacities that have more than one contiguous branching site [24] (Fig. 1f).

CT images were reviewed retrospectively and independently by two cardiothoracic radiologists (A with 25 years of experience and B with 15 years of experience) who knew that patients had suspected COVID-19 exposure history but were blinded to any other laboratory or RT-PCR data. When a discrepancy of image feature definition and diagnoses existed between the two radiologists, the final result was decided according to their consensus.

\section{Statistical analysis}

Continuous variables were presented as medians with interquartile ranges (IQR). Categorical variables were

Table 4 Discriminative performance of prediction for COVID-19

\begin{tabular}{lllll}
\hline Variable & AUC & SE & $P$-value & $95 \% \mathrm{Cl}$ \\
\hline Combined CT Score & 0.854 & 0.045 & $<0.001^{*}$ & 0.752 to 0.926 \\
\hline
\end{tabular}

${ }^{*} P<0.05$ was considered as statistical significant summarized as counts and percentages. Differences between the two groups (confirmed COVID-19 vs. confirmed non-COVID-19) were compared for continuous and categorical variables by a Mann-Whitney $U$ test and chi-squared test, respectively. $p<0.05$ was considered significant. The receiver operating characteristic (ROC) curve was used to determine the cut-off value of COVID-19 prediction. The area under the curve (AUC) and Youden index were computed. The performance of each cut-off value was evaluated as sensitivity, specificity, positive and negative predictive values. All analyses were performed with MedCalc Statistical Software, version 18.11.3.

\section{Results}

\section{Characteristics and clinical laboratory findings}

This retrospective study included 73 patients, of which 30 were confirmed as COVID-19 positive by RT-PCR, and 43 were classified as non-COVID-19 who were finally confirmed by RT-PCR as COVID-19-negative and positive for other pathogens or clinical treatment (Table 1). In this study, 37 patients were male $(50.7 \%)$ and 36 patients were female (49.3\%). There was no significant difference in sex between these two groups; moreover, $53.3 \%$ of the COVID-19 group were male and $46.5 \%$ of the non-COVID-19 group were female. Patients in the COVID-19 group were significantly older (median age 54 years, IQR $36-64, p<0.01$ ) than those in the non-COVID-19 group (median age 37 years, IQR $32-$ 
47). The majority of the COVID-19 group had an exposure history related to Wuhan $(n=24,80 \%)$ while most patients $(n=30,69.8 \%)$ of non-COVID-19 group had no history of Hubei contact or cluster onset. Fever (61.6\%) and cough $(67.1 \%)$ were the most common symptoms presented in the majority of both groups. Only COVID19 had 4 (13.3\%) patients presenting with diarrhoea. In the non-COVID-19 group, 3 patients (7\%) and 1 patient (2.3\%) had symptoms of running/stuffy nose and chest pain, respectively, which were not present in the COVID-19 group in our study. The white blood cell count and lymphocyte count of all patients were within normal range. However, the white blood cell count of the COVID-19 group (median $5.43 \mathrm{~g} / \mathrm{L}$, IQR $4.25-6.12$ $\mathrm{g} / \mathrm{L})$ was significantly lower $(p<0.001)$ than that of the non-COVID-19 group (median $7.67 \mathrm{~g} / \mathrm{L}$, IQR 6.73-9.06 $\mathrm{g} / \mathrm{L})$. The lymphocyte count in the COVID-19 group (median $1.32 \mathrm{~g} / \mathrm{L}$, IQR $1.08-1.69 \mathrm{~g} / \mathrm{L}$ ) was also significantly lower $(p<0.001)$ than that in the non-COVID-19 group (median $1.93 \mathrm{~g} / \mathrm{L}$, IQR $1.54-2.64 \mathrm{~g} / \mathrm{L}$ ).

\section{CT imaging findings}

High-resolution chest CT scans were performed for all 30 patients with COVID-19 and 43 patients with nonCOVID-19. Selected chest CT image features are shown in Table 3. Of the 7 positive signs, GGO with or without consolidation ( $n=66,90.4 \%$ in all patients) was one of the most common image features shared by the COVID$19(n=27,90 \%)$ and non-COVID-19 $(n=39,90.7 \%)$ groups, and it was not significantly different between the two groups $(p=0.921)$. Although other positive image features could be recognized in both the COVID-19 and non-COVID-19 groups, there were significant differences between the two groups $(p<0.05)$. In particular,

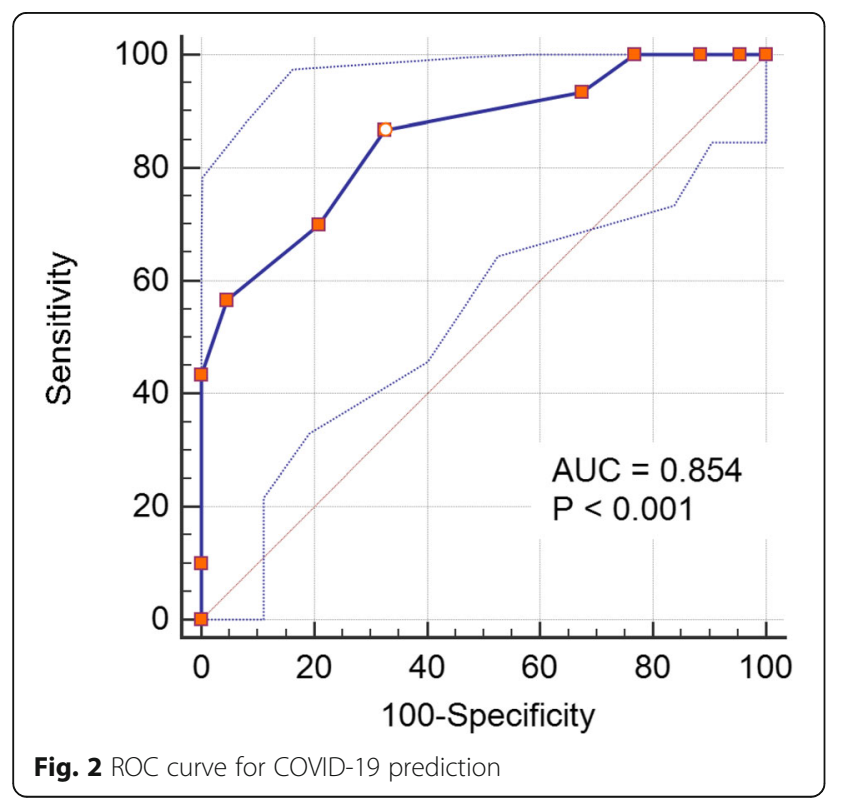

rounded GGO $(n=8,26.7 \%)$ and subpleural bandlike GGO $(n=14,46.7 \%)$ were pretty common in COVID-19 but rarely seen in non-COVID-19 (rounded GGO, $\mathrm{n}=1$, 2.3\%; subpleural bandlike GGO, $n=2,4.7 \%, p<0.001$ ).

In the 4 negative signs, the tree-in-bud sign (centrilobular nodules) could only be detected in the non-COVID-19 group ( $n=6.14 \%, p=0.01$ ) while other negative signs presented more in the non-COVID-19 group than in the COVID-19 group with a significant difference $(p<0.05)$.

Based on the 11 CT image features listed in Table 3, we calculated the total score for each patient. The total score ranged from -4 to 7 . The median score of the COVID-19 group was 4 (IQR 2-5), which was significantly higher $(p<0.001)$ than that of the non-COVID-19 group (median 2, IQR 0-2). The performance of our scoring system for the diagnosis of COVID-19 is shown in Table 4. The receiver operating characteristic (ROC) curve of the combined CT image features analysis revealed that the area under the curve (AUC) of our scoring system was 0.854 (95\%CI: 0.752-0.926), $p<0.001$ (Fig. 2). The cut-off values yielded a sensitivity of $56.67 \%$ and a specificity of $95.35 \%$ for a score $>4$, a sensitivity of $100 \%$ and a specificity of $23.26 \%$ for a score $>0$, and a sensitivity of $86.67 \%$ and a specificity of $67.44 \%$ for a score $>2$ (Table 5).

\section{Discussion}

COVID-19 is a severe and easily transmissible infectious disease spreading all around the world. Chest CT examination plays a vital role in the initial and early diagnosis of COVID-19 [8]. Positive chest CT can be obtained before the initial positive RT-PCR. Given the varied isolation and treatment principles of suspected COVID-19 with epidemic history, it is important to focus on baseline CT findings that radiologists first encounter to differentiate non-COVID-19 from COVID-19 in the patients' first consultation at a general hospital. Although Bai et al. [25] revealed that radiologists were capable of distinguishing COVID-19 from viral pneumonia upon chest $\mathrm{CT}$ with high specificity and moderate and varying specificity (24-94\%) among 7 different readers from China and the USA, an easily understood and simple method is still urgently needed in epidemic areas, especially areas lacking medical resources and well-trained radiologists. Compared with non-COVID-19 patients, COVID-19 patients are more likely to present with some CT image features according to previous studies. We have summarized the 7 most common imaging features in COVID-19 patients as a positive score point. All of the positive score points assessed in our study were significantly different between the two groups, except for GGO with or without consolidation. GGO can result from the pathology of alveolar damage filling with blood, pus, water or cells $[9,26]$ in viral infections, including 
Table 5 Prediction performance of COVID-19 with different cut-off values

\begin{tabular}{llllllllll}
\hline Cut-off & TP & FP & TN & FN & Youden Index & Sensitivity $(95 \% \mathrm{Cl})$ & Specificity $(95 \% \mathrm{Cl})$ & PPV $(95 \% \mathrm{Cl})$ & NPV $(95 \% \mathrm{Cl})$ \\
\hline $\mathbf{> 4}$ & 17 & 2 & 41 & 13 & 0.5202 & $56.67(37.4$ to 74.5$)$ & $95.35(84.2$ to 99.4$)$ & $89.5(67.9$ to 97.2$)$ & $75.9(67.6-82.7)$ \\
$\mathbf{>}$ & 26 & 14 & 29 & 4 & 0.5411 & $86.67(69.3$ to 96.2$)$ & $67.44(51.5$ to 80.9$)$ & $65.0(54.2-74.5)$ & $87.9(74.0-94.9)$ \\
$\mathbf{> 0}$ & 30 & 33 & 10 & 0 & 0.2326 & $100.0(88.4$ to 100.0$)$ & $23.26(11.8$ to 38.6) & $47.6(43.5-51.7)$ & $100.0(-)$ \\
\hline
\end{tabular}

COVID-19, and bacterial infections. GGO with or without consolidation is to some extent related to the different course of the disease. However, consolidation would be increased in the progressive stage (5-8 days) [10]. To reduce interference by consolidation, our study confined the cohort to within 7 days after onset of symptoms. The small COVID-19 virus, $60-140 \mathrm{~nm}$ in diameter [1], could go straight to the terminal alveoli, reasonably favouring peripheral distribution while other, much larger pathogens would not pass through the alveolar pores easily. The 'crazy-paving' pattern results from thickening of the interlobular septa, and it can be seen primarily in any airspace, interstitial, or mixed disease [27]. Rounded GGO as well as subpleural bandlike GGO are very conspicuous and characteristic signs at the first glance on examination of the COVID-19 CT images. Although there was no explanation for these two signs, they could be easily detected; we used them as our positive scoring points.

In our design, we added some negative points to make a hierarchical diagnosis. Based on the fact that most of the reported COVID-19 cases affected more than 2 lobes of the lungs, only one lobe involvement was taken as a negative scoring point. Meanwhile, single-lobe infection has been reported in some cases of community-acquired pneumonia [28]. Some progressive COVID-19 cases may affect the central area from the peripheral lung [15]. An image showing only central (peribronchovascular) distribution indicates distal small airway wall destruction or peribronchovacular infection, which is similar to the reason for the tree-in-bud pattern. The pathogenesis of bronchial wall thickening can be inflammatory damage of the bronchial wall, which may serve as a potential indicator for bacterial pneumonia [29], resulting in the destruction of bronchial wall structure and proliferation of fibrous tissue fibrosis [19]. It is more likely to present in severe COVID-19 patients but rarely in ordinary patients at the early stage. All three signs strongly indicated nonCOVID-19 infection and were taken as distinctive negative scoring points.

Based on these typical image features of COVID-19 and other common non-COVID-19 pneumonia, a simple and practical scoring system has been established in our study. When tested in our group of suspected COVID19 cases, the scoring system achieved good diagnosis performance with $\mathrm{AUC}=0.854$ (95\%CI: 0.752-0.926).
Our larger cohorts and good-to-excellent diagnostic performance confirmed a similar study of Himoto et al. [30] in Japan with simpler criteria and moderate-to-excellent inter-reader concordance. Their study proposed a statistically proven powerful tool for triaging patients based on positive COVID-19 image features while ours added some negative values. Using a score $>4$ as a cut-off, our scoring system showed a high specificity of $95.35 \%$ (95\%CI: 84.2 to $99.4 \%$ ) and made only 2 false-positive diagnoses (false-positive rate: $4.65 \%$ ); a score $>4$ could be strongly suspected for COVID-19. For suspected cases with a score $>4$, even negative results were shown several times by RT-PCR; hence, we still suggest that repeat RT-PCR testing is necessary. If using a score $>0$ as the diagnostic cut-off, the sensitivity is $100 \%$ with no false-negative $(0 \%)$ diagnoses of COVID-19; thus cases with scores $\leq 0$ are less likely to be COVID-19. We can exclude COVID-19 in these cases with more confidence and reduce the testing by RT-PCR. Patients with scores of 0-4 should be classified as suspected COVID-19 and be quarantined under medical surveillance followed by at least two RT-PCR tests according to the suggestion of the newest edition of guidelines.

There are several limitations in our study. First, the analysis in our study was limited to one general hospital, but all cases had fulfilled the suspected COVID19 criteria with exposure history, respiratory symptoms and normal or decreased white blood cell and lymphocyte counts. Our criteria might have missed rare cases with normal chest CT and negative RT-PCR at the first consultation. Second, with a small number of confirmed cases, we cannot set another group to verify the reliability of the scoring system. Future studies including more confirmed patients and multicentre studies would optimize the practical applicability of the scoring system and enable the verification of its reliability.

\section{Conclusion}

With exposure history and respiratory symptoms in this epidemic period, the present simple scoring system provides rapid detection, which may enable better control of COVID-19 spread through medical management as well as reduce the larger public health surveillance and response systems. 


\section{Abbreviations}

COVID-19: 2019 novel coronavirus disease; RT-PCR: Reverse transcriptionpolymerase chain-reaction; GGO: Ground glass opacification

\section{Acknowledgements}

Not applicable.

\section{Authors' contributions}

$\mathrm{LL}, \mathrm{ZL}$ and XS contributed to the design and implementation of the concept. $\mathrm{LL}$ and $\mathrm{ZL}$ contributed equally to this work. $\mathrm{J}, \mathrm{JH}, \mathrm{ZL}$ and $\mathrm{CZ}$ contributed in collecting and analysing patients' clinical data and CT image features. JL, LL and XS contributed to the evaluation and the recording of the CT image features. LL, ZL, JH and CZ contributed in searching the scientific literatures. YJ contributed in the statistical analysis of the data. All authors contributed to the writing and reviewing of the paper. All authors read and approved the final manuscript.

\section{Funding}

This study was supported by High Level-Hospital Program, Health Commission of Guangdong Province, China (No: HKUSZH201901026). The funders had no role in the study design, data collection and analysis, decision to publish, or preparation of the work.

\section{Availability of data and materials}

The datasets analyzed during the current study available from the corresponding author on reasonable request.

\section{Ethics approval and consent to participate}

Due to the retrospective design of the study and there was minimal to no risk or benefit to enrolled patients. Institutional Review Board approval and an informed consent was waived by the Ethics Committees of the University of Hongkong-Shenzhen Hospital.

\section{Consent for publication}

Not applicable.

\section{Competing interests}

The authors declare that they have no competing interests.

\section{Author details}

'Department of Radiology, The University of Hong Kong - Shenzhen Hospital, No.1, Haiyuan road Futian District, Shenzhen 518000, China. ${ }^{2}$ Department of Core Laboratory, The University of Hong Kong - Shenzhen Hospital, Hospital, No.1, Haiyuan road Futian District, Shenzhen 518000, China.

\section{Received: 30 March 2020 Accepted: 28 April 2020}

\section{Published online: 07 May 2020}

\section{References}

1. Authority MAaH. Guidlines for the diagnosis and treatment of coronavirus 2019 (COVID-19) infection by the national health commission (trial version 7). National Health Commision of the People's Republic of China website. 2020. http://en.nhc.gov.cn/2020-03/29/c_78469.htm. Accessed 3 Mar 2020.

2. Guan WJ, Ni ZY, Hu Y, Liang WH, Ou CQ, He JX, Liu L, Shan H, Lei CL, Hui DSC et al. Clinical characteristics of Coronavirus disease 2019 in China. N Engl J Med. 2020. https://doi.org/10.1056/NEJMc2005203.

3. Xie X, Zhong Z, Zhao W, Zheng C, Wang F, Liu J. Chest CT for Typical 2019nCoV Pneumonia. Relationship to Negative RT-PCR Testing. Radiology. 2020. https://doi.org/10.1148/radiol.2020200343.

4. Fang Y, Zhang H, Xie J, Lin M, Ying L, Pang P, Ji W. Sensitivity of Chest CT for COVID-19: Comparison to RT-PCR. Radiology. 2020. https://doi.org/10. 1148/radiol.2020200432

5. Ai T, Yang Z, Hou H, Zhan C, Chen C, Lv W, Tao Q, Sun Z, Xia L. Correlation of Chest CT and RT-PCR Testing in Coronavirus Disease 2019 (COVID-19) in China: a Report of 1014 Cases. Radiology. 2020. https://doi.org/10.1148/ radiol.2020200642.

6. Kanne JP. Chest CT Findings in 2019 Novel Coronavirus (2019-nCoV) Infections from Wuhan, China: Key Points for the Radiologist. Radiology. 2020. https://doi.org/10.1148/radiol.2020200241.
7. Bernheim A, Mei X, Huang M, Yang Y, Fayad ZA, Zhang N, Diao K, Lin B, Zhu X, Li K et al. Chest CT findings in Coronavirus Disease-19 (COVID-19): relationship to duration of infection. Radiology. 2020. https://doi.org/10. 1148/radiol.2020200463.

8. Chung M, Bernheim A, Mei X, Zhang N, Huang M, Zeng X, Cui J, Xu W, Yang Y, Fayad ZA et al. CT imaging features of 2019 Novel Coronavirus (2019-nCoV). Radiology. 2020. https://doi.org/10.1148/ radiol.2020200230.

9. Song F, Shi N, Shan F, Zhang Z, Shen J, Lu H, Ling Y, Jiang Y, Shi Y. Emerging Coronavirus 2019-nCoV Pneumonia. Radiology. 2020. https://doi. org/10.1148/radiol.2020200274.

10. Pan F, Ye T, Sun P, Gui S, Liang B, Li L, Zheng D, Wang J, Hesketh RL, Yang L et al. Time course of lung changes on chest $C T$ during recovery from 2019 Novel Coronavirus (COVID-19) Pneumonia. Radiology. 2020. https://doi.org/ 10.1148/radiol.2020200370.

11. Zu ZY, Jiang MD, Xu PP, Chen W, Ni QQ, Lu GM, Zhang LJ. Coronavirus disease 2019 (COVID-19): a perspective from China. Radiology. 2020. https:// doi.org/10.1148/radiol.2020200490.

12. Pan Y, Guan H, Zhou S, Wang Y, Li Q, Zhu T, Hu Q, Xia L. Initial CT findings and temporal changes in patients with the novel coronavirus pneumonia (2019-nCoV): a study of 63 patients in Wuhan, China. Eur Radiol. 2020. https://doi.org/10.1007/s00330-020-06731-X.

13. Shi H, Han X, Jiang N, Cao Y, Alwalid O, Gu J, Fan Y, Zheng C. Radiological findings from 81 patients with COVID-19 pneumonia in Wuhan, China: a descriptive study. Lancet Infect Dis. 2020. https://doi.org/10.1016/S14733099(20)30086-4.

14. Xu X, Yu C, Qu J, Zhang L, Jiang S, Huang D, Chen B, Zhang Z, Guan W, Ling $Z$ et al. Imaging and clinical features of patients with 2019 novel coronavirus SARS-CoV-2. Eur J Nucl Med Mol Imaging. 2020. https://doi.org/ 10.1002/jmv.25822.

15. Xu YH, Dong JH, An WM, Lv XY, Yin XP, Zhang JZ, Dong L, Ma X, Zhang HJ, Gao BL. Clinical and computed tomographic imaging features of Novel Coronavirus Pneumonia caused by SARS-CoV-2. J Infect. 2020. https://doi. org/10.1016/j.jinf.2020.02.017.

16. Koo HJ, Lim S, Choe J, Choi SH, Sung H, Do KH. Radiographic and CT features of viral pneumonia. Radiographics. 2018;38(3):719-39.

17. Franquet T. Imaging of pulmonary viral pneumonia. Radiology. 2011;260(1): 18-39.

18. Franquet T. Imaging of community-acquired pneumonia. J Thorac Imaging. 2018:33(5):282-94.

19. Hansell DM, Bankier AA, MacMahon H, McLoud TC, Muller NL, Remy J. Fleischner society: glossary of terms for thoracic imaging. Radiology. 2008; 246(3):697-722.

20. Nakanishi M, Nakashima K, Takeshita M, Yagi T, Nakayama T, Kiguchi T, Yamada $\mathrm{H}$. Ability of high-resolution computed tomography to distinguish Mycoplasma pneumoniae pneumonia from other bacterial pneumonia: Significance of lateral bronchial lesions, less air bronchogram, and no peripheral predominance. Respir Investig. 2020. https://doi.org/10.1016/j. resinv.2020.01.006

21. Ye Z, Zhang Y, Wang Y, Huang Z, Song B. Chest CT manifestations of new coronavirus disease 2019 (COVID-19): a pictorial review. Eur Radiol. 2020. https://doi.org/10.1007/s00330-020-06801-0.

22. Lee CH. The crazy-paving sign. Radiology. 2007:243(3):905-6.

23. Murata K, Khan A, Herman PG. Pulmonary parenchymal disease: evaluation with high-resolution CT. Radiology. 1989:170(3 Pt 1):629-35.

24. Minault Q, Karol A, Veillon F, Venkatasamy A. Tree-in-bud sign. Abdom Radiol (NY). 2018;43(11):3188-9.

25. Bai HX, Hsieh B, Xiong Z, Halsey K, Choi JW, Tran TML, Pan I, Shi LB, Wang DC, Mei J et al. Performance of radiologists in differentiating COVID-19 from viral pneumonia on chest CT. Radiology. 2020. https://doi.org/10.1148/radiol. 2020200823.

26. Chong S, Kim TS, Cho EY. Herpes simplex virus pneumonia: high-resolution CT findings. Br J Radiol. 2010;83(991):585-9.

27. Hochhegger B, Schumacher Neto R, Marchiori E. Crazy-paving pattern. J Bras Pneumol. 2016;42(1):76.

28. Ishiguro T, Yoshii Y, Kanauchi T, Hoshi T, Takaku Y, Kagiyama N, Kurashima K, Takayanagi N. Re-evaluation of the etiology and clinical and radiological features of community-acquired lobar pneumonia in adults. J Infect Chemother. 2018;24(6):463-9.

29. Kunihiro Y, Tanaka N, Kawano R, Yujiri T, Kubo M, Ueda K, Gondo T, Kobayashi T, Matsumoto T. Differential diagnosis of pulmonary infections in 
immunocompromised patients using high-resolution computed tomography. Eur Radiol. 2019;29(11):6089-99.

30. Himoto Y, Sakata A, Kirita M, Hiroi T, Kobayashi Kl, Kubo K, Kim H, Nishimoto A, Maeda C, Kawamura A et al. Diagnostic performance of chest CT to

differentiate COVID-19 pneumonia in non-high-epidemic area in Japan. Jpn J Radiol. 2020. https://doi.org/10.1007/s11604-020-00958-w.

\section{Publisher's Note}

Springer Nature remains neutral with regard to jurisdictional claims in published maps and institutional affiliations.

Ready to submit your research? Choose BMC and benefit from:

- fast, convenient online submission

- thorough peer review by experienced researchers in your field

- rapid publication on acceptance

- support for research data, including large and complex data types

- gold Open Access which fosters wider collaboration and increased citations

- maximum visibility for your research: over $100 \mathrm{M}$ website views per year

At BMC, research is always in progress.

Learn more biomedcentral.com/submissions 